\title{
Changes in the rheological properties of stirred acid milk gels as induced by the acidification procedure
}

\author{
Marie RenAN ${ }^{1}$, Véronique ARNOULT-DELEST ${ }^{2}$, Denis PÂQUET ${ }^{2}$, \\ Gérard BRULÉ ${ }^{1}$, Marie-Hélène FAMELART ${ }^{1 *}$ \\ ${ }^{1}$ INRA, Agrocampus Rennes, UMR1253, Science et Technologie du Lait et de l'Euf, \\ 65 rue de St-Brieuc, 35042 Rennes Cedex, France \\ ${ }^{2}$ DANONE Research, RD 128, 91767 Palaiseau Cedex, France
}

Received 6 September 2007 - Accepted 29 October 2007

\begin{abstract}
The aim of this study was to compare the rheological properties of stirred acid milk gels, acidified using two different acidification procedures. Pre-heated milks were acidified either by means of glucono- $\delta$-lactone (GDL gel) at $20^{\circ} \mathrm{C}$ or by incubation with lactic acid bacteria (lactic gel) at $38{ }^{\circ} \mathrm{C}$. The latter procedure gave a harder acid set gel with a more heterogeneous structure. Once formed, the gels were filtered and stirred, then immediately characterised using the low-amplitude dynamic oscillation method for $20 \mathrm{~h}$ at $4{ }^{\circ} \mathrm{C}$ or creep measurement at $4{ }^{\circ} \mathrm{C}$. The stirred gels were stored at $4{ }^{\circ} \mathrm{C}$ for $28 \mathrm{~d}$, during which the $\mathrm{pH}$ and the viscosity at $64 \mathrm{~s}^{-1}$ were measured. After stirring, the lactic gel made at $38{ }^{\circ} \mathrm{C}$ had a higher instantaneous elastic modulus, a higher viscosity and showed a greater increase in the elastic modulus over $20 \mathrm{~h}$ compared with the stirred GDL gel. The viscosity of both stirred gels progressively increased during storage at $4{ }^{\circ} \mathrm{C}$, but that of GDL acidified gels increased 3.5 times more than that of lactic gels. The procedure used to prepare the set acid gels had notable effects on the interactions formed within $20 \mathrm{~h}$ and $28 \mathrm{~d}$ of storage of stirred gels.
\end{abstract}

stirred yoghurt / set yoghurt / acid milk gel / rheology

摘要 - 酸化过程引起摚拌型酸奶凝胶流变特性的变化。本文比较了两种不同的酸化过程 引起摚拌型酸奶凝胶流变特性的变化。预热后的牛奶分别在 $20^{\circ} \mathrm{C}$ 用 $\delta$-葡萄糖酸内酯酸化 (GDL凝胶) 和在 $38{ }^{\circ} \mathrm{C}$ 下接种乳酸菌 (乳酸凝胶)。后者形成的凝固型酸凝胶较硬并具有较 多的异性结构。将形成的凝胶立即过滤和摚拌, 然后在 $4{ }^{\circ} \mathrm{C} 、 20 \mathrm{~h}$ 后用低振幅动态振荡法 或在 $4{ }^{\circ} \mathrm{C}$ 用蠕变测量法观察凝胶特性的变化。摚拌后的凝胶在 $4{ }^{\circ} \mathrm{C}$ 下咜存 $28 \mathrm{~d}$, 其间测定 摚拌型凝胶的 $\mathrm{pH}$ 和秥度 (在 $64 \mathrm{~s}^{-1}$ )。与摚拌型的 GDL 凝胶相比, $38^{\circ} \mathrm{C}$ 下形成的乳酸凝胶 摚拌后具有较高的瞬时弹性模量和黏度, 并且在 $20 \mathrm{~h}$ 后其弹性模量显著增加。在 $4{ }^{\circ} \mathrm{C}$ 的䛎 藏过程中两种摚拌型凝胶的咷度均显著地增加, 但是 GDL 凝胶秥度增加的程度比乳酸凝胶 多 3-5 倍。凝固型酸奶的制备过程对摚拌型凝胶在 $20 \mathrm{~h}$ 和 $28 \mathrm{~d}$ 败藏期内凝胶的性质有显著 地影响。

摚拌型酸奶 / 凝固型酸奶 / 酸乳凝胶 / 流变性

* Corresponding author (通讯作者): marie-helene.famelart@ rennes.inra.fr 


\begin{abstract}
Résumé - Effet de la procédure d'acidification sur les propriétés rhéologiques des gels acides brassés. Le but de ce travail est de comparer les propriétés rhéologiques des gels acides brassés acidifiés par 2 procédures différentes. Le lait traité thermiquement était acidifié soit par addition de glucono delta lactone à $20^{\circ} \mathrm{C}$ (gel GDL), soit par incubation avec des bactéries lactiques à $38{ }^{\circ} \mathrm{C}$ (gel lactique). Cette dernière procédure donnait des gels plus fermes avec une structure davantage hétérogène. Une fois formés, les gels étaient filtrés et brassés, puis immédiatement caractérisés en utilisant la méthode dynamique d'oscillations en faible amplitude pendant $20 \mathrm{~h}$ à $4{ }^{\circ} \mathrm{C}$ et par fluage à $4{ }^{\circ} \mathrm{C}$. Les gels brassés étaient stockés à $4{ }^{\circ} \mathrm{C}$ pendant $28 \mathrm{j}$ pendant lesquels le $\mathrm{pH}$ et la viscosité à $64 \mathrm{~s}^{-1}$ étaient mesurés. Après brassage, le gel lactique préparé à $38^{\circ} \mathrm{C}$ avait un plus grand module élastique instantané, une plus grande viscosité et montrait une plus grande augmentation du module élastique pendant $20 \mathrm{~h}$, comparé au gel GDL brassé. La viscosité des 2 types de gel brassé augmentait progressivement pendant le stockage à $4{ }^{\circ} \mathrm{C}$, mais elle augmentait 3,5 fois plus dans le gel GDL que dans le gel lactique. La procédure appliquée pour préparer le gel acide avait des effets notables sur les interactions formées à $20 \mathrm{~h}$ et à $28 \mathrm{j}$ de stockage des gels brassés.
\end{abstract}

yaourt brassé / yaourt ferme / gel acide / rhéologie

\section{INTRODUCTION}

It is well known that the procedure and the temperature used during the acidification of pre-heated milk result in set acid gels showing different rheological properties and microstructures. Lucey et al. [15] compared gels made from heated milk and acidified using GDL at $30{ }^{\circ} \mathrm{C}$ or a bacterial culture at $42{ }^{\circ} \mathrm{C}$. Acidification with GDL increased many parameters compared with acidification with lactic acid bacteria: the initial rate of acidification, the elastic modulus $\left(G^{\prime}\right)$, the yield stress and strain, the permeability and whey separation. The microstructure of bacterial gels is unaffected by using incubation temperatures between 30 and $42{ }^{\circ} \mathrm{C}$, while GDL gels are more heterogeneous at $42{ }^{\circ} \mathrm{C}$. According to many authors, increasing the incubation temperature leads to a higher gelation $\mathrm{pH}$. Consequently, a higher gelation $\mathrm{pH}$ produces a gel composed of more mineralised particles and thus yields a microstructure with larger pore sizes and different viscoelastic behaviours. Permeability also increased, as did pore sizes and whey separation [13,15, 16, 18]. Conversely, some authors $[5,11,19]$ reported that a high acidification temperature leads to an increase in the elastic modulus and in the firmness of set yoghurt.

Changes in the microstructure of set yoghurt can be explained by many fac- tors: a greater rearrangement of particles at $40{ }^{\circ} \mathrm{C}$ compared with $20^{\circ} \mathrm{C}[17,18]$, a temperature-dependent dissociation of casein during acidification [4], a strengthening of hydrophobic interactions with increasing temperatures [5], the rate of calcium phosphate solubilisation [13] or the balance between the rate of proton production and diffusion $[9,10]$. Bacteria grow in colonies which produce lactic acid in small localised areas, therefore forming gels with large void spaces, as reported by numerous authors $[2,7,8,20]$. The aggregation of casein micelles depends on the amino acid residues present on the micelle surface, on the physicochemical properties of these residues and therefore on the $\mathrm{pH}$ of the aqueous phase. When the acidification rate is high, a substantial difference between intra- and extra-micellar $\mathrm{pH}$ may occur and lead to a network of casein particles containing different levels of mineralisation. Acidification by GDL leads to a more homogeneous distribution of proton production and may have a different impact on the intra-micellar $\mathrm{pH}$.

While the effect of the acidification procedure is well described for set acid gels, very little is known on the behaviour of stirred acid milk gels. According to many authors, the rheological properties of stirred yoghurts can be related to those of set yoghurts $[3,5,11]$. Increasing the temperature of incubation has been shown to 
lead to firmer set acid gels which retained higher viscosities $[5,11]$ and higher elastic moduli [5] after stirring. According to Lankes et al. [11], a higher rate of acidification, which altered the kinetics of protein network formation, may explain these results. As the loss tangent $(\tan \delta)$ remained unaffected by the incubation temperature and stirring, it has been suggested that similar interactions are involved in both set and stirred systems [11].

The aim of the present study was to relate the final rheological properties of stirred acid gels to the microstructures of the set acid gel and to understand the reassociation of gel particles due to stirring. Two set gels were made using two different procedures: GDL at $20{ }^{\circ} \mathrm{C}$ or incubation with lactic acid bacteria at $38{ }^{\circ} \mathrm{C}$. These two procedures are known to induce large differences in the kinetics of acidification, gelation and in physical properties of the set gels, such as heterogeneity and porosity. The rheological properties of the two stirred acid gels were compared.

However, it must be kept in mind that the two procedures used to produce the gels cannot be directly compared, as they differ both by the mode and the temperature of acidification. The 2 methods have been used solely to produce 2 different structures and to show the effect of these different structures on the rheological properties and quality of the stirred gels.

\section{MATERIALS AND METHODS}

\subsection{Materials}

Milk was reconstituted from low-heat skim milk powder (BBA Lactalis Industrie, Bourgbarré, France) at $140 \mathrm{~g} \cdot \mathrm{kg}^{-1}$ dry matter into deionised water and equilibrated for $1 \mathrm{~h}$. One litre was heat-treated through a spiral stainless steel tube immersed in a water bath, as described in Laligant et al. [9]. The temperature of the milk was measured every $5 \mathrm{~s}$ using a thermocouple, the SR Mini system and Specview software (TC SA, Dardilly, France). The milk was held at $90{ }^{\circ} \mathrm{C}$ for $10 \mathrm{~min}$ after a warm-up time of $9 \mathrm{~min}$, rapidly cooled in ice-water and stored at $4{ }^{\circ} \mathrm{C}$. Including the time taken for temperature increase, holding and decrease, the equivalent time $\left(\tau_{90^{\circ}} \mathrm{C}\right)$ of the overall treatment at $90^{\circ} \mathrm{C}$ was about $16 \mathrm{~min}$ for whey protein denaturation as calculated by:

$$
\tau_{90^{\circ} \mathrm{C}}=\mathrm{d} t \sum 10^{\frac{\theta-90^{\circ} \mathrm{C}}{z}}
$$

with $\theta$ the temperature measured at each 5-s interval $(\mathrm{d} t)$ and $z$ the increase in temperature that reduces the decimal reduction time by 10 . According to Jeantet et al. [6], the $z$ value is 6 for whey protein denaturation.

\subsection{Acidification}

Non-ropy strains of Lactobacillus bulgaricus (LB 340) and Streptococcus thermophilus (TA 060) were purchased from Danisco (Dangé St Romain, France) and added to milk at 0.002 and 0.02 unit $\cdot \mathrm{L}^{-1}$, respectively. This milk was stored between 0 and $4{ }^{\circ} \mathrm{C}$ for $\approx 7 \mathrm{~h}$ and then incubated at $38{ }^{\circ} \mathrm{C}$ for $\approx 12 \mathrm{~h}$. Milk of another trial was directly mixed at $20{ }^{\circ} \mathrm{C}$ with GDL at $19.6 \mathrm{~g} \cdot \mathrm{kg}^{-1}$ and stored for $\approx 20 \mathrm{~h}$, until a $\mathrm{pH}$ of 4.4 was reached.

Gelation was observed under lowamplitude dynamic oscillation using an AR1000 rheometer (TA Instruments, Guyancourt, France) with coaxial cylinders (outer and inner diameter, 5 and $4.61 \mathrm{~cm}) 0.001$ strain and $1 \mathrm{~Hz}$. An Inlab 423 electrode (Mettler-Toledo, Viroflay, France) was placed in the geometry to measure the $\mathrm{pH}$. A plastic cover was inserted to avoid evaporation. Three bacterial gels and 2 GDL-induced gels were prepared, as the GDL acidification was more reproducible than the bacterial acidification. 

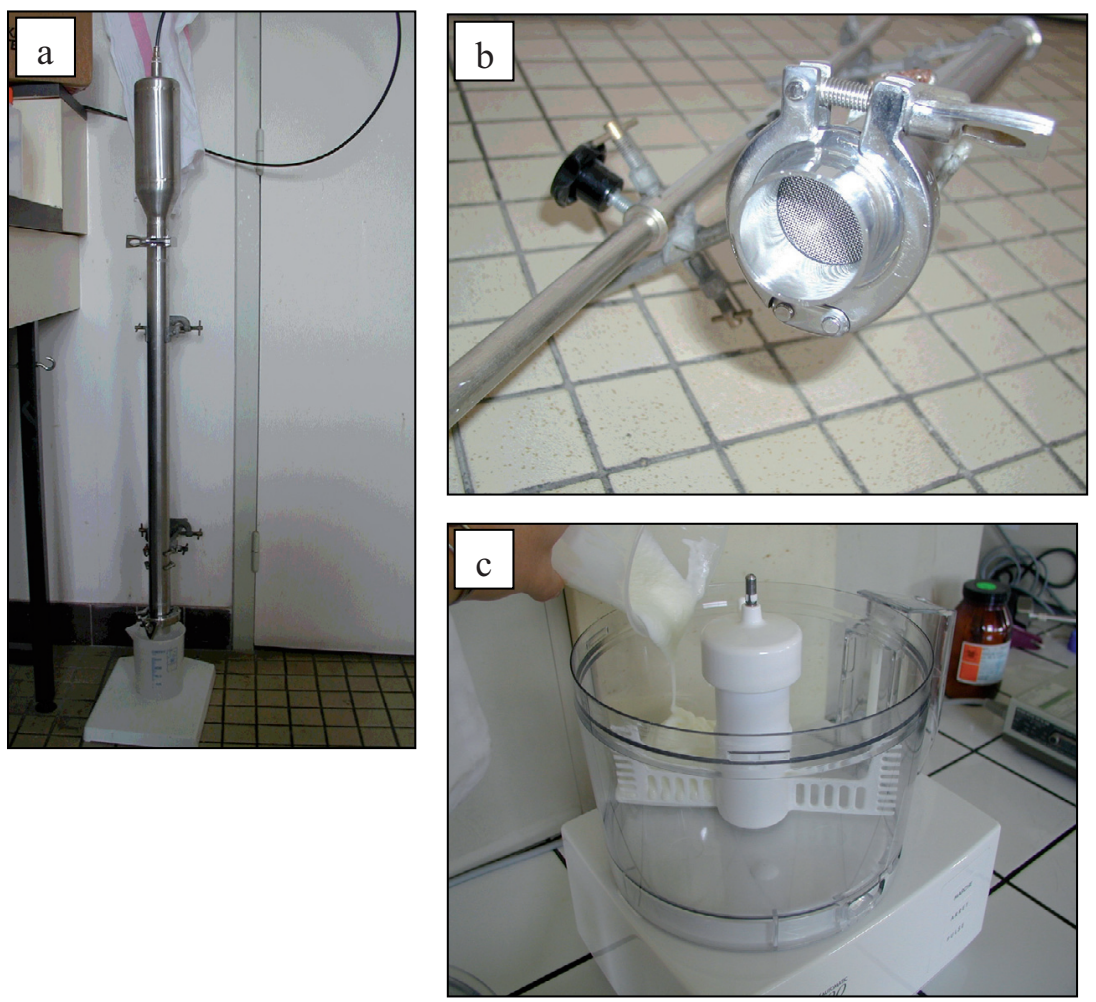

Figure 1. The stirring system used for stirring the acid gel; a: steel tube with a filter at the bottom; b: filter composed of a mesh, view from the bottom; c: the home food processor.

\subsection{Confocal microscopy}

Fluorescent rhodamine B isothiocyanate (RITC, Sigma, Saint-Quentin Fallavier, France) was added to milk at a final concentration of $20 \mathrm{mg} \cdot \mathrm{kg}^{-1}$ and mixed with the milk for $15 \mathrm{~min}$ at $4{ }^{\circ} \mathrm{C}$ before GDL or starter addition. Forty $\mu \mathrm{L}$ of fluorescent-labelled milk were introduced into the confocal microscope on a concave slide covered by a coverslip held in place with nail varnish. Gels were observed at $\mathrm{pH} 4.4$ after $20 \mathrm{~h}$ at $20{ }^{\circ} \mathrm{C}$ and $7 \mathrm{~h}$ at $38^{\circ} \mathrm{C}$, for GDL and bacterial gels, respectively. RITC binds to proteins and allowed the protein network to be observed using a $\mathrm{Kr} / \mathrm{Ar}$ laser at excitation wavelengths of $568 \mathrm{~nm}$ and detection at $590 \mathrm{~nm}$, with a $40 \times$ oil immersion (numerical aperture 1.0) objective using a Leica TCS NT (Leica Microsystems, Heidelberg, Germany) at zoom 1 and 4. The two-dimensional images had a resolution of $1024 \times 1024$ pixels.

\subsection{Stirring}

The 3 bacterial gels and 2 GDL-induced gels $(390 \mathrm{~g})$ at $\mathrm{pH} 4.4$ were broken by forcing the gels under compressed air through a steel cylindrical tube $(70 \mathrm{~cm}$ high and an internal diameter of $3.5 \mathrm{~cm}$ ) with a mesh of 350-400 $\mu \mathrm{m}$ holes at the end (Fig. 1). Stirring was then completed using a home food processor (Magimix, Vincennes, France) 
for $10 \mathrm{~s}$ at $300 \mathrm{rpm}$. This process gave a smooth and homogeneous stirred product, with very few air bubbles. The particle size distribution in the current stirred gels measured by laser light scattering in a Mastersizer 2000 (Malvern Instruments, Malvern, UK) was very close to that of commercial nonfat yoghurt (results not shown).

\subsection{Characterisation of stirred gels}

Stirred gels were held at $4{ }^{\circ} \mathrm{C}$ for $10 \mathrm{~min}$ before four creep measurements of $5 \mathrm{~min}$ each were performed at increasing stresses of $0.3,0.6,0.8$ and $1 \mathrm{~Pa}$. Between every 2 creep measurements, the sample was maintained without strain for $5 \mathrm{~min}$. Increasing stress allowed the linear viscoelastic model to be checked with successive curves intertwining. The compliance was best fitted with a Burger's model made up by the "in series" coupling of a Maxwell and a Voigt element, as described in Lapasin et al. [12]:

$$
\begin{aligned}
J(t)= & 1 / \mathrm{G}_{\mathrm{c} 0}+t / \eta_{\mathrm{c} 0}+ \\
& \left(1 / \mathrm{G}_{\mathrm{c} 1}\right)\left(1-\exp \left(-t \times \mathrm{G}_{\mathrm{c} 1} / \eta_{\mathrm{c} 1}\right)\right)
\end{aligned}
$$

where $J$ is the compliance, $\mathrm{G}_{\mathrm{c} 0}$ and $\eta_{\mathrm{c} 0}$ are the modulus and viscosity of the Maxwell element and $\mathrm{G}_{\mathrm{c} 1}$ and $\eta_{\mathrm{c} 1}$ are the modulus and viscosity of the Voigt element. The retardation time $\left(\tau_{\mathrm{c}}=\eta_{\mathrm{c} 1} / \mathrm{G}_{\mathrm{c} 1}\right)$ was calculated for the Voigt element. Ninety-nine percent of the final value of the spring is reached at $3 \tau_{1}$. Compliance data were fitted by this method with a confidence interval for R-square at [0.9902-0.9967]. As analysis of variance showed that the applied stress value had no significant effect on the fitted parameters, the parameter values for all stresses were therefore averaged.

The short-term recovery of viscoelastic properties of the stirred gels was measured by low-amplitude dynamic oscillation rheometry over $20 \mathrm{~h}$ at $4{ }^{\circ} \mathrm{C}$ using the
AR1000 rheometer with an acrylic cone of $6 \mathrm{~cm}$ diameter and $3^{\circ} 59^{\prime}$ at 0.001 strain and $0.16 \mathrm{~Hz}$. The short-term recovery was defined as $\mathrm{G}^{\prime}$ increase over $20 \mathrm{~h}$. Values of the storage modulus $\left(\mathrm{G}^{\prime}\right)$ and loss tangent $(\tan \delta)$ were adjusted with a double exponential equation:

$$
\begin{aligned}
\mathrm{G}^{\prime}(t)= & \mathrm{G}_{0}^{\prime}+\mathrm{G}_{1}^{\prime}\left(1-\exp \left(-t / \tau_{\mathrm{G}^{\prime} 1}\right)\right) \\
& +\mathrm{G}_{2}^{\prime}\left(1-\exp \left(-t / \tau_{\mathrm{G}^{\prime} 2}\right)\right) \\
\tan \delta(t)= & \tan \delta_{0}-\tan \delta_{1}\left(1-\exp \left(-t / \tau_{\tan 1}\right)\right) \\
& -\tan \delta_{2}\left(1-\exp \left(-t / \tau_{\tan 2}\right)\right)
\end{aligned}
$$

where $\tau_{\mathrm{G}^{\prime} 1}$ and $\tau_{\mathrm{G}^{\prime} 2}$, or $\tau_{\tan 1}$ and $\tau_{\tan 2}$ are the time constants of the 2 successive steps for the values of $\mathrm{G}^{\prime}$ or tan $\delta$, respectively. Actually, short-term recovery of viscoelastic moduli has already been described by a first post-stirring rapid procedure of $1-2 \mathrm{~h}$, followed by a slower one [1,3], and is well fitted by this 2-step equation of increase.

Dynamic viscosity measurements were also performed in triplicate on each stirred gel stored at $4{ }^{\circ} \mathrm{C}$ for 0,7 and $28 \mathrm{~d}$ of storage. Measurements were carried out at $4{ }^{\circ} \mathrm{C}$ with a steel cone $\left(2^{\circ}-5\right.$-cm diameter $)$ in the VT550 viscometer (Haake, Thermo Electron, Cergy-Pontoise, France) for $5 \mathrm{~min}$ at the constant shear rate of $64 \mathrm{~s}^{-1}$, and the viscosity obtained at $10 \mathrm{~s}$ and 5 min was analysed. Breakdown of the gels was evaluated by the decrease in viscosity between $10 \mathrm{~s}$ and $5 \mathrm{~min}$ of shear. Long-term recovery was defined as the viscosity increase during storage.

\subsection{Statistical analysis}

Differences between measurements were tested by a Student's $t$-test with $P<0.05$.

\subsection{Fitting of data}

Data were fitted to equations by the non-linear least square fitter by processing successive Levenberg-Marquardt iterations (Origin 6.1, OriginLab Corporation). 


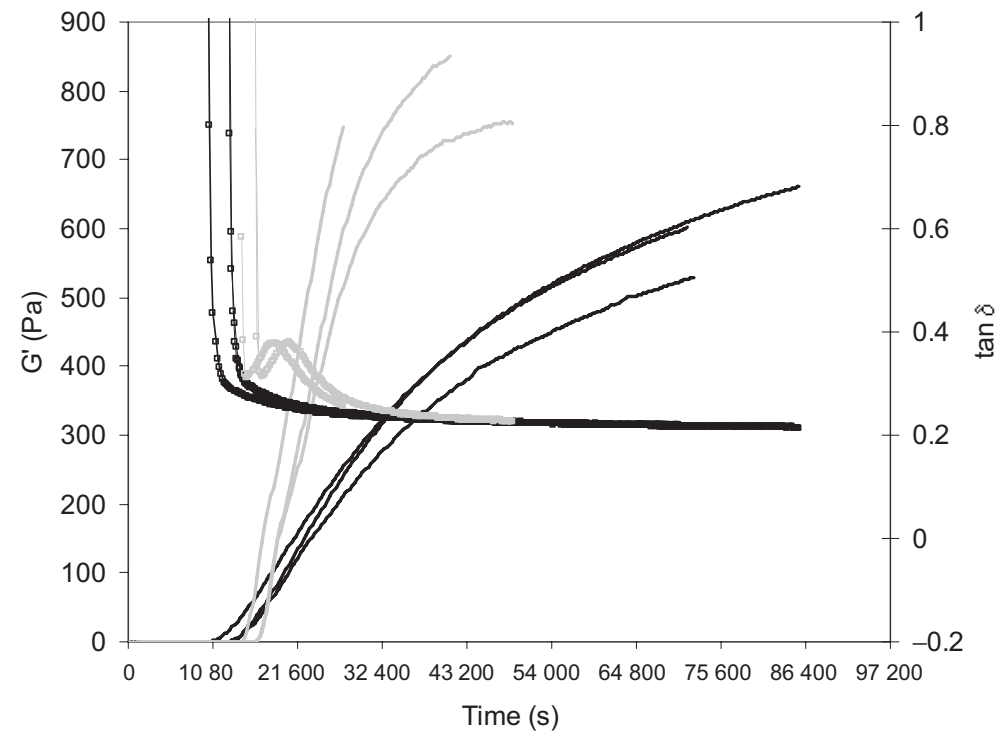

Figure 2. Viscoelastic properties of heat-treated milk during acidification with glucono-deltalactone at $20^{\circ} \mathrm{C}\left(\square: \mathrm{G}^{\prime} ; \square-\tan \delta\right)$ or a bacterial culture at $38^{\circ} \mathrm{C}\left(\square: \mathrm{G}^{\prime} ; \square: \tan \delta\right)$ in coaxial cylinders versus time. Zero time for bacterial acidification was taken at the time where the temperature reached $38^{\circ} \mathrm{C}$. Three repetitions for each procedure.

\section{RESULTS}

As expected, the two acidification procedures used led to different set gels (Fig. 2 and Tab. I). With GDL at $20{ }^{\circ} \mathrm{C}$, the gelation $\mathrm{pH}$ was lower (5.07 compared with 5.32), and the gel did not show a maximum for $\tan \delta$, while this maximum appeared at $\mathrm{pH} 4.98 \pm 0.09$ with the bacterial acidification. The final moduli and tan $\delta$ of GDL gels were lower than for the bacterial acidification, resulting in a softer gel with a more solid-like behaviour as compared with the bacterial gel.

In the bacterial gel, magnification $(\times 40)$ revealed large spaces or pores without fluorescence (Fig. 3a), while in the GDL gel, the structure was more homogeneous, with a regular porosity (Fig. 3b). These spaces are thought to be occupied by macro-colonies of bacteria. Figures $3 \mathrm{c}$ and $3 \mathrm{~d}$ show the microstructure in an area of the gel not containing macro-colonies
( $\times 40$ - zoom 4$)$. The two structures were not very different, except that the GDL gel appeared a little denser compared with the bacterial gel, with a slightly smaller porosity.

In the following discussion, the acid gel obtained by the GDL procedure will be referred to as the soft gel and the gel obtained by fermentation will be referred to as the hard gel. Also, the hard bacterial gel had a more heterogeneous structure compared with the soft GDL gel.

The $\mathrm{pH}$ of the hard and soft gels $(4.18 \pm$ 0.03 and $4.12 \pm 0.01$, respectively) after $28 \mathrm{~d}$ of storage was not significantly different $(P>0.05)$.

The compliance data of the just-stirred gels were fitted with Burger's model (Fig. 4 and Tab. II). Stirred gel behaved with an instantaneous compliance which indicated the stiffness of the material, a retarded compliance indicating a time-dependent 
Table I. Parameters obtained by the dynamic rheological method during acidification of heated milk (mean \pm standard deviation). Gelation was defined when $\mathrm{G}^{\prime}=1 \mathrm{~Pa}$.

\begin{tabular}{lcc}
\hline Parameters & $\begin{array}{c}\text { Chemical acidification } \\
\text { at } 20^{\circ} \mathrm{C}(n=2)^{*}\end{array}$ & $\begin{array}{c}\text { Bacterial acidification } \\
\text { at } 38^{\circ} \mathrm{C}(n=3)\end{array}$ \\
\hline Gelation $\mathrm{pH}$ & $5.07^{\mathrm{a}} \pm 0.05$ & $5.32^{\mathrm{b}} \pm 0.11$ \\
Max tand & - & $0.3773 \pm 0.0016$ \\
$\mathrm{pH}$ of max tand & - & $4.98 \pm 0.09$ \\
$\mathrm{G}^{\prime}$ at $\mathrm{pH} 4.6(\mathrm{~Pa})$ & $484^{\mathrm{a}} \pm 39$ & $655^{\mathrm{b}} \pm 82$ \\
tand at $\mathrm{pH} 4.6$ & $0.223^{\mathrm{a}} \pm 0.005$ & $0.258^{\mathrm{b}} \pm 0.015$ \\
\hline
\end{tabular}

$* n$ : Number of measurements.

-: No local maximum in tan $\delta$.

a,b: Means with different superscripts on the same row differ significantly $(P<0.05)$.
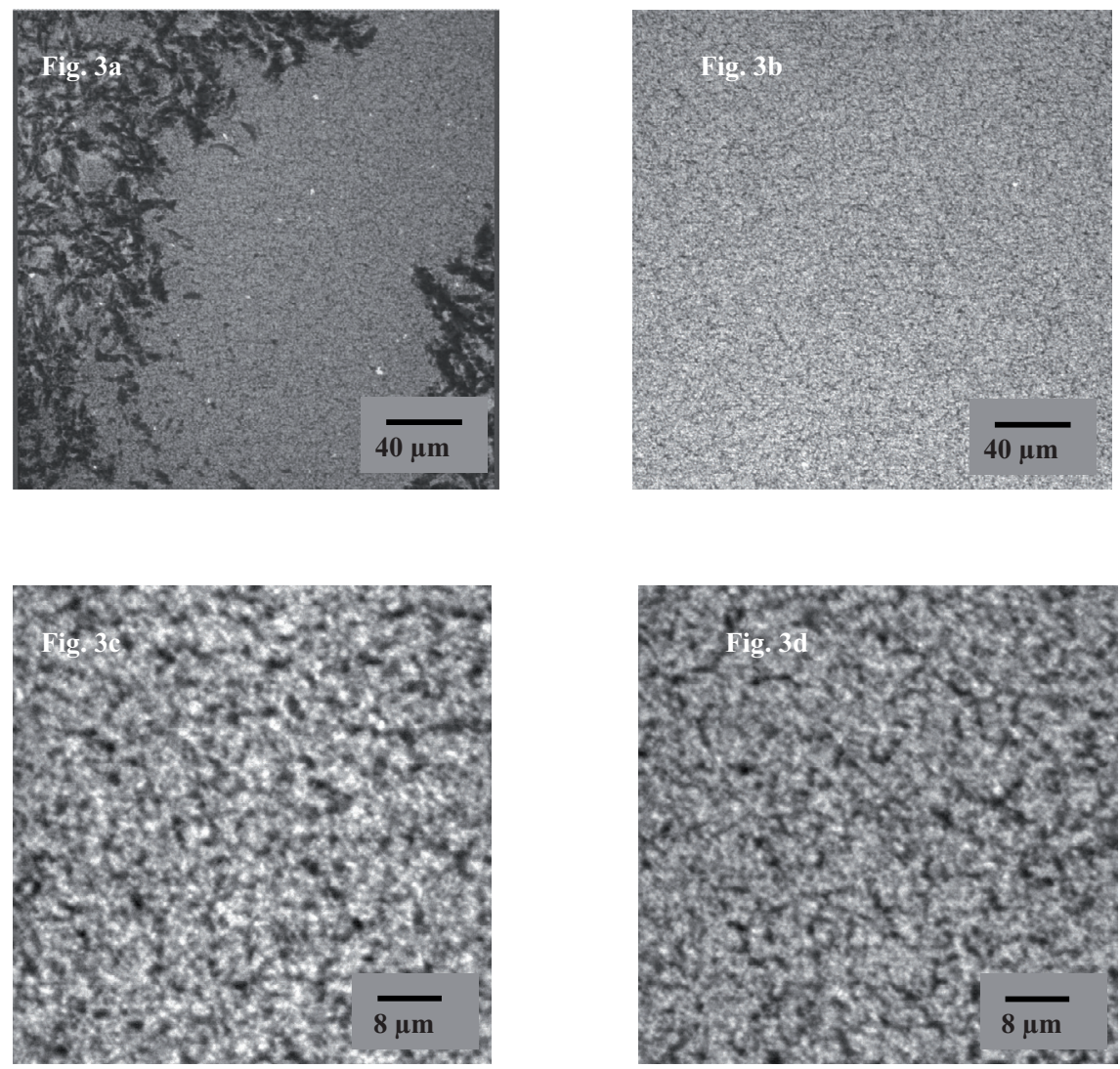

Figure 3. Microstructure of acid gels obtained with yoghurt starters at $38{ }^{\circ} \mathrm{C}$ for $12 \mathrm{~h}(\mathrm{a}(\times 40)$; $\mathrm{c}(\times 40$-zoom 4$))$ and with GDL addition at $20^{\circ} \mathrm{C}$ for $20 \mathrm{~h}(\mathrm{~b}(\times 40)$; $\mathrm{d}(\times 40$-zoom 4$))$. 


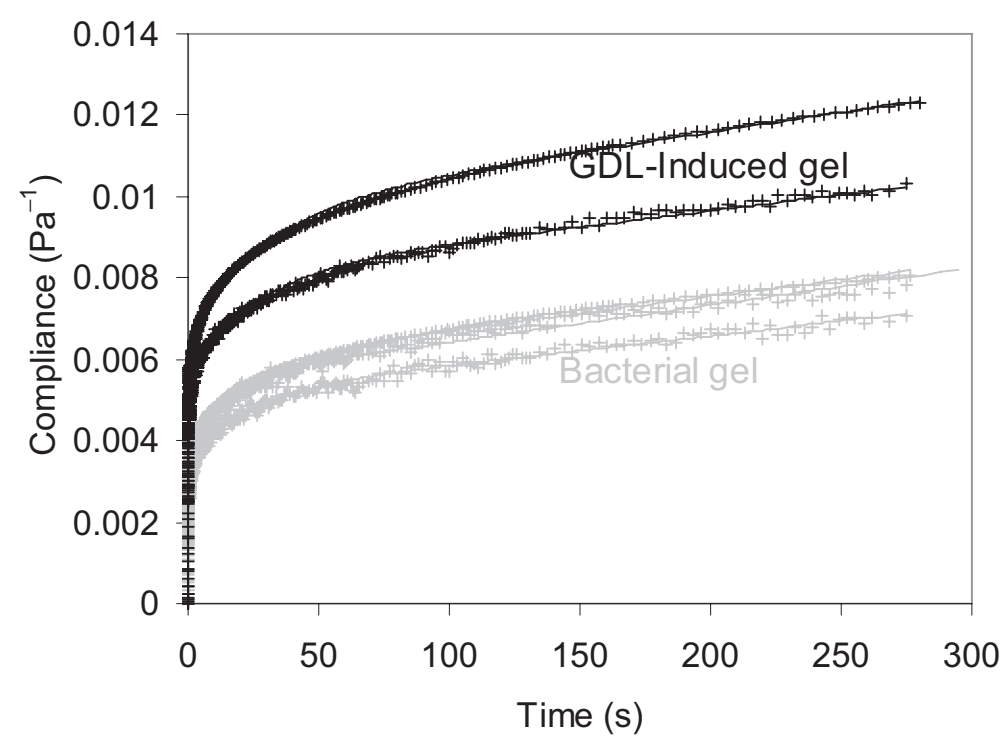

Figure 4. Creep measurements on stirred acid gels with cone-plate geometry. Stirred gel at day 0 (the day of stirring) was subjected to 4 creep measurements of 5 min each at $4{ }^{\circ} \mathrm{C}$ at increasing stresses of $0.3,0.6,0.8$ and $1 \mathrm{~Pa}$. Milk was acidified with glucono-delta-lactone at $20^{\circ} \mathrm{C}(+)$ or a bacterial culture at $38^{\circ} \mathrm{C}(+)$.

Table II. Parameters of the Burger's model obtained from creep measurements on GDL and bacterial stirred acid gels at day 0 (mean \pm standard deviation):

$J(t)=1 / \mathrm{G}_{\mathrm{c} 0}+t / \eta_{\mathrm{c} 0}+\left(1 / \mathrm{G}_{\mathrm{c} 1}\right)(1-\exp (-t \times$ $\left.\left.\mathrm{G}_{\mathrm{c} 1} / \eta_{\mathrm{c} 1}\right)\right)$.

\begin{tabular}{lcc}
\hline Parameters & $\begin{array}{c}\text { GDL } \\
(n=8)^{*}\end{array}$ & $\begin{array}{c}\text { Bacterial culture } \\
(n=12)\end{array}$ \\
\hline $\mathrm{G}_{\mathrm{c} 0}(\mathrm{~Pa})$ & $175^{\mathrm{a}} \pm 18$ & $279^{\mathrm{b}} \pm 21$ \\
$\eta_{\mathrm{c} 0}(\mathrm{~Pa} \cdot \mathrm{s})$ & $105605^{\mathrm{a}} \pm 11181$ & $127542^{\mathrm{b}} \pm 23243$ \\
$\mathrm{G}_{\mathrm{c} 1}(\mathrm{~Pa})$ & $344^{\mathrm{a}} \pm 48$ & $514^{\mathrm{b}} \pm 73$ \\
$\eta_{\mathrm{c} 1}(\mathrm{~Pa} \cdot \mathrm{s})$ & $4118^{\mathrm{a}} \pm 590$ & $4877^{\mathrm{a}} \pm 1158$ \\
$\tau_{1}(\mathrm{~s}) \dagger$ & $23.5^{\mathrm{a}} \pm 2.2$ & $17.6^{\mathrm{b}} \pm 4.5$ \\
\hline
\end{tabular}

${ }^{*} n$ : Number of measurements.

$\dagger \tau_{1}$ : The recovery times, $\eta_{\mathrm{c} 1} / \mathrm{G}_{\mathrm{cl}}$.

a,b: Means with different superscripts on the same row differ significantly $(P<0.05)$.

behaviour and a final flow. Except for the viscosity of the Voigt element, parameters of the Burgers model were significantly higher for the hard gel compared with the soft gel, meaning that the hard bacterial stirred gel had a higher instantaneous modulus and a higher viscosity of the dashpot component.

During the 1-2 $\mathrm{h}$ after stirring, the gels showed a strong recovery in $\mathrm{G}^{\prime}$ and $\mathrm{G}^{\prime \prime}$ and a decrease in $\tan \delta$ (Fig. 5), but it was not completed by $20 \mathrm{~h}$. Upon stirring, small pieces of gel were generated which were supposed to reassociate during storage, with an increased solid behaviour, probably due to the formation of new interactions. The fitted parameters of the double exponential equation are shown in Table III for $G^{\prime}$ and $\tan \delta$. Stirred gels from the soft GDL gels showed less rebodying with time. Their elastic moduli at $20 \mathrm{~h}$ was half that obtained from the hard gel. Initial values for $\mathrm{G}^{\prime}$ and $\tan \delta$ and $\mathrm{G}^{\prime}$ increase over the first step were different between the two gels, while there was no difference afterwards. However, the time constants of increase or decrease in 


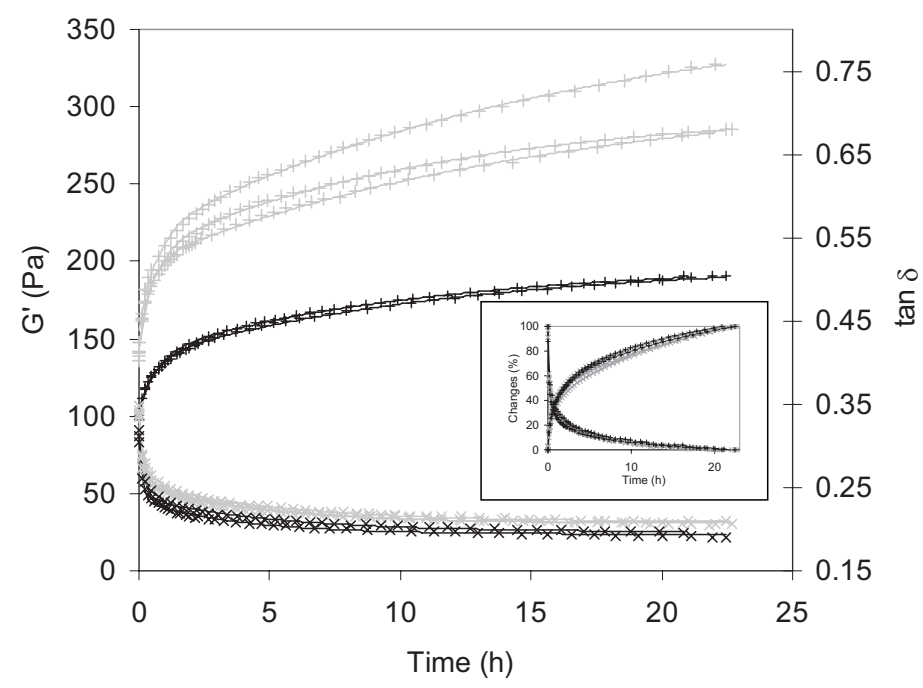

Figure 5. Storage modulus $(+,+)$ and tan $\delta(\times, \times)$ versus time after stirring of acid gels at $\mathrm{pH} 4.4$, in a cone-plate geometry at $4{ }^{\circ} \mathrm{C}$. Milk was acidified with GDL at $20{ }^{\circ} \mathrm{C}(+, \times)$ or a bacterial culture at $38{ }^{\circ} \mathrm{C}(+, \times)$. Lines are for the calculated values with the double exponential model. Relative changes in $\mathrm{G}^{\prime}$ and tan $\delta$ in the inserted curve.

Table III. Parameters of the double exponential equation for the increase in $\mathrm{G}^{\prime}$ or the decrease in $\tan \delta$ for $20 \mathrm{~h}$ after stirring, for GDL and bacterial stirred gels (mean \pm standard deviation): $\mathrm{G}^{\prime}(t)=\mathrm{G}_{0}^{\prime}+\mathrm{G}_{1}^{\prime}\left(1-\exp \left(-t / \tau_{\mathrm{G}^{\prime} 1}\right)\right)+\mathrm{G}_{2}^{\prime}(1$ $\left.-\exp \left(-t / \tau_{\mathrm{G}^{\prime} 2}\right)\right)$ $\tan \delta(t)=\tan \delta_{0}-\tan \delta_{1}\left(1-\exp \left(-t / \tau_{\tan 1}\right)\right)-$ $\tan \delta_{2}\left(1-\exp \left(-t / \tau_{\tan 2}\right)\right)$.

\begin{tabular}{lcc}
\hline Parameters & $\begin{array}{c}\text { GDL } \\
(n=2)^{*}\end{array}$ & $\begin{array}{c}\text { Bacterial culture } \\
(n=3)\end{array}$ \\
\hline $\mathrm{G}_{0}^{\prime}(\mathrm{Pa})$ & $102^{\mathrm{a}} \pm 2$ & $148^{\mathrm{b}} \pm 6$ \\
$\mathrm{G}_{1}^{\prime}(\mathrm{Pa})$ & $36^{\mathrm{a}} \pm 0$ & $59^{\mathrm{b}} \pm 3$ \\
$\tau_{\mathrm{G}^{\prime} 1}(\mathrm{~h})$ & $0.62^{\mathrm{a}} \pm 0.07$ & $0.56^{\mathrm{a}} \pm 0.12$ \\
$\mathrm{G}_{2}^{\prime}(\mathrm{Pa})$ & $60^{\mathrm{a}} \pm 3$ & $117^{\mathrm{a}} \pm 29$ \\
$\tau_{\mathrm{G}^{\prime} 2}(\mathrm{~h})$ & $11^{\mathrm{a}} \pm 1$ & $15^{\mathrm{a}} \pm 3$ \\
$\mathrm{G}_{\propto}^{\prime}(\mathrm{Pa})$ & 198 & 324 \\
$\tan \delta_{0}$ & $0.314^{\mathrm{a}} \pm 0.004$ & $0.342^{\mathrm{b}} \pm 0.03$ \\
$\tan \delta_{1}$ & $0.078^{\mathrm{a}} \pm 0.007$ & $0.087^{\mathrm{a}} \pm 0.005$ \\
$\tau_{\tan 1}(\mathrm{~h})$ & $0.173^{\mathrm{a}} \pm 0.052$ & $0.159^{\mathrm{a}} \pm 0.037$ \\
$\tan \delta_{2}$ & $0.041^{\mathrm{a}} \pm 0.001$ & $0.047^{\mathrm{b}} \pm 0.001$ \\
$\tau_{\tan 2}(\mathrm{~h})$ & $4.507^{\mathrm{a}} \pm 1.001$ & $4.772^{\mathrm{a}} \pm 0.423$ \\
$\tan \delta_{\propto}$ & 0.195 & 0.208 \\
\hline
\end{tabular}

$* n$ : Number of measurements.

a,b: Means with different superscripts on the same row differ significantly $(P<0.05)$. viscoelastic properties were not different between both types of gel, meaning that it took the same length of time to reach the total increase for the 2 kinds of gels, as shown in Figure 5.

The stirred acid gels were subjected to structural breakdown at $64 \mathrm{~s}^{-1}$ shear rate for $5 \mathrm{~min}$. Typical curves are shown in Figure 6. The viscosity of the samples decreased within the 5-min shearing and seemed to reach a steady state. Viscosity was measured after $10 \mathrm{~s}$ of shearing and the breakdown determined as the loss of viscosity between $10 \mathrm{~s}$ and $5 \mathrm{~min}$ (Tab. IV). Viscosity just after stirring of the hard bacterial gel was slightly higher as compared with the soft gel (Fig. 6), but the soft gel showed a much greater increase in the viscosity after $28 \mathrm{~d}$ of storage. The maximum increase in viscosity occurred between 0 and $7 \mathrm{~d}$ of storage (Tab. IV), as did structural breakdown. The higher the viscosity, the higher the breakdown. As shown in Table IV, except for the GDL stirred gel at day 0 , the breakdown was 


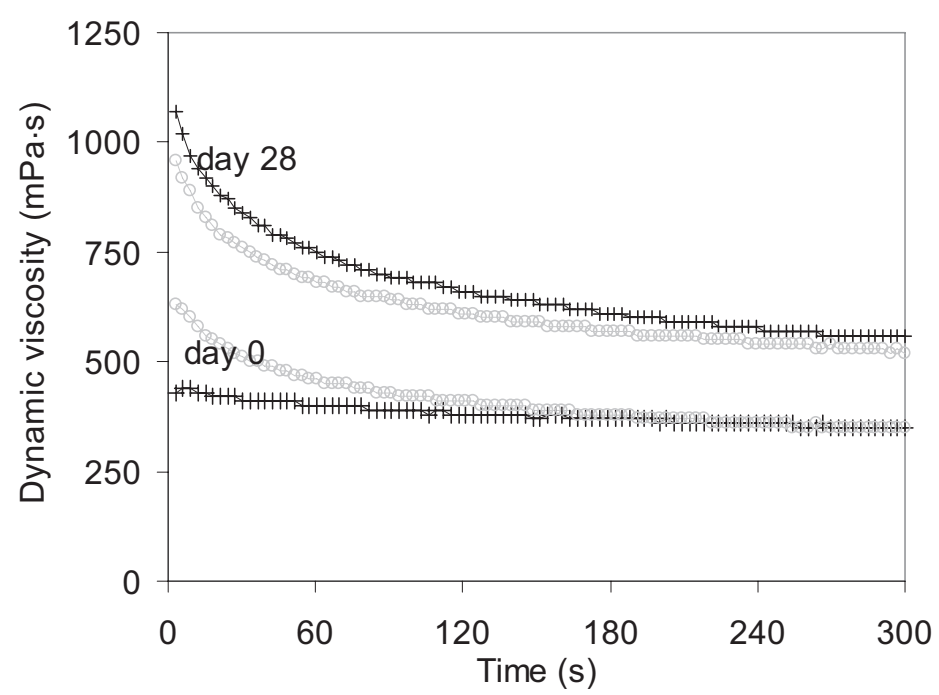

Figure 6. One example of viscosity changes in the stirred gel during 5 min shearing in cone-plate geometry $\left(2^{\circ}\right.$ and $5 \mathrm{~cm}$ diameter) at $4{ }^{\circ} \mathrm{C}$, measured on the day of stirring (day 0 ) or after $28 \mathrm{~d}$ (day 28): acid gels obtained with GDL $(+)$ or bacterial fermentation $(\bigcirc)$.

$40-43 \%$ of the viscosity value. The increase in viscosity during storage might be due to the recovery of low-energy bonds between gel particles, which are broken during shearing.

\section{DISCUSSION}

This study showed that set gels with different microstructures and rheological properties led to different quality of stirred gels. Just after stirring and over the initial $20 \mathrm{~h}$ of storage, the hard acid gel led to a viscoelastic stirred gel with many increased parameters as compared with the soft gel: the instantaneous elastic modulus, the viscosity of the dashpot component, the dynamic viscosity and the short-term recovery of its viscoelastic properties. Interestingly, after $28 \mathrm{~d}$ of storage at $4{ }^{\circ} \mathrm{C}$, the dynamic viscosity of the soft stirred gel increased 3.5 times more compared with the hard gel. This suggests that the interactions involved in a set acid gel had significant and opposing effects on short-term and long-term interactions formed during storage. According to Lee and Lucey [14], acid gels obtained at lower incubation temperatures $\left(32{ }^{\circ} \mathrm{C}\right.$ compared with $\left.44{ }^{\circ} \mathrm{C}\right)$ increased many parameters of acid gelation: the maximum of $\tan \delta$, the structure heterogeneity, as shown by a higher permeability coefficient, the elastic modulus and the yield stress. They also resulted in stirred gels with lower viscosities. These authors assumed that larger pores in the gel and a higher maximum of $\tan \delta$, which indicated the presence of weak spots and a greater susceptibility of structural rearrangements, respectively, can lead to local breakage and weaker interactions in the gel.

Many hypotheses could be suggested to explain the effect of the 2 modes of acidification on the rheological properties of the just-stirred gels. First, the hard bacterial gel had a higher gelation $\mathrm{pH}$ compared with the soft gel, and hence, micelle particles at the onset of aggregation might be more mineralised, more highly charged and less dissociated as compared with a gel formed at a lower $\mathrm{pH}$. According to Lee 
Table IV. Viscosity values (mean \pm standard deviation) by flow measurements at $64 \mathrm{~s}^{-1}$ in cone-plate geometry of the stirred acid gels stored at $4{ }^{\circ} \mathrm{C}$. Acid gels were obtained either by addition of GDL at $20^{\circ} \mathrm{C}$ or bacterial acidification at $38^{\circ} \mathrm{C}$. Measurements were carried out during a 5 -min flow. The viscosity $(\eta)$ is measured at $10 \mathrm{~s}$ and breakdown was calculated as the decrease in viscosity between $10 \mathrm{~s}$ and $5 \mathrm{~min}$ shear.

\begin{tabular}{|c|c|c|}
\hline & $\begin{array}{c}\text { GDL } \\
(n=6)^{*}\end{array}$ & $\begin{array}{c}\text { Bacterial culture } \\
(n=9)\end{array}$ \\
\hline$\overline{\eta_{0}(\mathrm{mPa} \cdot \mathrm{s}) \dagger}$ & $509^{\mathrm{a}} \pm 28$ & $610^{b} \pm 24$ \\
\hline$\eta_{7}(\mathrm{mPa} \cdot \mathrm{s})$ & $1216^{\mathrm{a}} \pm 345$ & $797^{b} \pm 65$ \\
\hline$\eta_{28}(\mathrm{mPa} \cdot \mathrm{s})$ & $1310^{\mathrm{a}} \pm 541$ & $845^{\mathrm{a}} \pm 148$ \\
\hline$\left(\eta_{28}-\eta_{0}\right)(\mathrm{mPa} \cdot \mathrm{s})$ & $818^{a} \pm 136$ & $235^{\mathrm{b}} \pm 32$ \\
\hline Breakdown $_{0}(\mathrm{mPa} \cdot \mathrm{s})$ & $129^{\mathrm{a}} \pm 32$ & $243^{b} \pm 14$ \\
\hline Breakdown $_{7}(\mathrm{mPa} \cdot \mathrm{s})$ & $525^{\mathrm{a}} \pm 172$ & $343^{\mathrm{a}} \pm 34$ \\
\hline Breakdown $_{28}(\mathrm{mPa} \cdot \mathrm{s})$ & $571^{\mathrm{a}} \pm 295$ & $351^{\mathrm{a}} \pm 77$ \\
\hline Breakdown ${ }_{0} / \eta_{0}(\%)$ & $25^{\mathrm{a}} \pm 5$ & $40^{\mathrm{a}} \pm 2$ \\
\hline Breakdown $/ \eta_{7}(\%)$ & $43^{\mathrm{a}} \pm 2$ & $43^{\mathrm{a}} \pm 1$ \\
\hline Breakdown $28 / \eta_{28}(\%)$ & $42^{\mathrm{a}} \pm 5$ & $41^{\mathrm{a}} \pm 2$ \\
\hline
\end{tabular}

$* n$ : Number of measurements.

$\dagger: 0$ subscript means just after stirring; 7 subscript means for stirred gel stored for $7 \mathrm{~d}$ at $4{ }^{\circ} \mathrm{C} ; 28$ subscript means for stirred gel stored for $28 \mathrm{~d}$ at $4{ }^{\circ} \mathrm{C}$.

a,b: Means with different superscripts on the same row differ significantly $(P<0.05)$.

and Lucey [13], when dissociation continues within the gel, it leads to a higher susceptibility to structural rearrangements in the set gel and probably after stirring. This can also lead to a higher increase in $\mathrm{G}^{\prime}$ and viscosity after stirring. Moreover, in the hard bacterial gel, the production of acid was not as uniform as in a chemical gel, because bacteria are not uniformly dispersed in the milk and grow as macro-colonies, producing protons in a few small localised areas. These protons need to diffuse from the colonies to micellar particles to reduce ionisation, charge and mineralisation of casein particles $[9,10]$. Stirring such a gel may accelerate the equilibration of mineral dissociation, casein partition, gel structure and $\mathrm{pH}$, which can lead to greater structural rearrangements, thus enhancing rebodying. Furthermore, a higher temperature during acidification $\left(38^{\circ} \mathrm{C}\right.$ compared with $20{ }^{\circ} \mathrm{C}$ ) may lead to increased hydrophobic interactions inside the particles. This led to a more compact particle structure, with lower contact area, and consequently fewer interactions between casein micelles [13]. In addition, more numerous and stronger hydrophobic interactions at higher temperatures led to a higher stiffness of inter- and intra-particle bonds and to a lower possibility of structural rearrangements. This was confirmed by the lower fractal dimension of acid aggregates at higher temperatures $\left(40{ }^{\circ} \mathrm{C}\right.$ versus $10{ }^{\circ} \mathrm{C}$ ), meaning a more compact structure of particles and a more porous structure of the final network [21]. These last two effects could lower the rheological properties in the set gel and also in the stirred gel. Moreover, stirring may create particles which have altered surface properties (hydrophobic or electrostatic properties), depending on the kinetics and the temperature of acidification, which could lead to different inter-particle interactions. As a higher incubation temperature increases the intra-particle hydrophobicity, this could lead to less hydrophobic surface area of aggregating particles during the texture recovery and to a reduced likelihood of hydrophobic inter-particle bonds being formed. This would probably impede the possibility of rebodying. Finally, when gelation occurs at a higher $\mathrm{pH}$ value, the initial interactions formed may further stress the structures and may prevent further bond formation as the $\mathrm{pH}$ decreases. Stirring reduced this stress and increased the contact between particles which may facilitate more rearrangements, and increased the formation of new interactions between protein particles. In conclusion, acidification of milk with bacteria led to the higher rebodying of the acid juststirred gel with the cited effects probably involved. 
Just after stirring the soft gel showed a lower dynamic viscosity than the hard gel, but after $28 \mathrm{~d}$ of storage at $4{ }^{\circ} \mathrm{C}$, it was the more viscous. In fact, for the soft gel obtained by GDL addition at $20{ }^{\circ} \mathrm{C}$, the viscosity increased more than twofold from the day of stirring to $7 \mathrm{~d}$ of storage, while the viscosity of the hard gel obtained by fermentation at $38{ }^{\circ} \mathrm{C}$ showed only a very small increase. It would therefore be better manufacturing an acid gel with much lower solid properties, to obtain a highly viscous stirred gel. Strong and weak interactions in the stirred gels were responsible for solid and flow properties of stirred acid gel, respectively. An increase in both of these was observed. As the soft gels were formed at a lower temperature, hydrophobic interactions may be less significant to the gel structure, and therefore other interactions were involved in these gels. The texture recovery could be due to the resetting of interactions already present in the set gel or to the formation of new interactions. Assuming the former hypothesis, stirred gels formed from set gels at $20^{\circ} \mathrm{C}$ may be more capable of reorganising at $4{ }^{\circ} \mathrm{C}$, in the absence of hydrophobic interactions, compared with gels formed at a higher temperature, giving higher viscosities after $7 \mathrm{~d}$.

\section{CONCLUSIONS}

The set acid gel obtained with lactic acid bacteria showed a more heterogeneous structure and a higher viscoelastic modulus, and led to a stirred acid gel with a higher viscosity and higher viscoelastic modulus at day 0 , but to a significantly lower dynamic viscosity after $28 \mathrm{~d}$ of storage. The stirring of the bacterial gel could lead to structural reorganisation due to the reduction of heterogeneity and to a rapid rebodying, whereas manufacturing the GDL gel at a lower temperature suggests that reorganisation was more likely to occur during the cold storage of the stirred gel for $28 \mathrm{~d}$.

\section{REFERENCES}

[1] Arshad M., Paulsson M., Dejmek P., Rheology of build-up, breakdown, and rebodying of acid casein gels, J. Dairy Sci. 76 (1993) 3310-3316.

[2] Bottazzi V., Bianchi F., Types of microcolonies of lactic acid bacteria, formation of void spaces and polysaccharides in yoghurt, Sci. Tecnica Lattiero-Casearia. 37 (1986) 297-315.

[3] Cayot P., Fairise J.F., Colas B., Lorient D., Brulé G., Improvement of rheological properties of firm acid gels by skim milk heating is conserved after stirring, J. Dairy Res. 70 (2003) 423-431.

[4] Cobos A., Horne D.S., Muir D.D., Rheological properties of acid milk gels. I. Effect of composition, process and acidification conditions on products from recombined milks, Milchwissenschaft 50 (1995) 444-448.

[5] Haque A., Richardson R.K., Morris E.R., Effect of fermentation temperature on the rheology of set and stirred yogurt, Food Hydrocoll. 15 (2001) 593-602.

[6] Jeantet R., Roignant M., Brulé G., Traitements thermiques, in: Génie des Procédés Appliqués à l'Industrie Laitière, Tec \& Doc, Paris, France, 2001, pp. 45-73.

[7] Kalab M., Scanning electron microscopy of dairy products: An overview, Scan. Electr. Microsc. 3 (1979) 261-272.

[8] Kalab M., Allan-Wojtas P., Phipps-Todd B.E., Development of microstructure in set-style nonfat yoghurt. A review, Food Microstruct. 2 (1983) 51-66.

[9] Laligant A., Famelart M.H., Brulé G., Piot M., Paquet D., Fermentation by lactic bacteria at two temperatures of pre-heated reconstituted milk. I - Behaviour of proteins and minerals, Lait 83 (2003) 181-192.

[10] Laligant A., Famelart M.H., Paquet D., Brulé G., Fermentation by lactic bacteria at two temperatures of pre-heated reconstituted milk. II - Dynamic approach of the gel construction, Lait 83 (2003) 307-320.

[11] Lankes H., Ozer H.B., Robinson R.K., The effect of elevated milk solids and incubation temperature on the physical properties of natural yoghurt, Milchwissenschaft 53 (1998) 510-513.

[12] Lapasin R., De Lorenzi L., Pricl S., Torriano G., Linear viscoelasticity of yoghurt, in: Texture of Fermented Milk Products and 
Dairy Desserts, IDF special issue 9802, Vicenza, Italy, 5-6 May 1997, Int. Dairy Fed., Brussels, Belgium, 1997, pp. 34-40.

[13] Lee W.J., Lucey J.A., Structure and physical properties of yogurt gels: Effect of inoculation rate and incubation temperature, J. Dairy Sci. 87 (2004) 3153-3164.

[14] Lee W.J., Lucey J.A., Impact of gelation conditions and structural breakdown on the physical and sensory properties of stirred yogurts, J. Dairy Sci. 89 (2006) 2374-2385.

[15] Lucey J.A., Tamehana M., Singh H., Munro P.A., A comparison of the formation, rheological properties and microstructure of acid skim milk gels made with a bacterial culture or glucono-delta-lactone, Food Res. Int. 31 (1998) 147-155

[16] Lucey J.A., Teo C.T., Munro P.A., Singh H., Microstructure, permeability and appearance of acid gels made from heated skim milk, Food Hydrocoll. 12 (1998) 159-165.

[17] Lucey J.A., van Vliet T., Grolle K., Geurts T., Walstra P., Properties of acid casein gels made by acidification with glucono-deltalactone. I. Rheological properties, Int. Dairy J. 7 (1997) 381-388.

[18] Lucey J.A., van Vliet T., Grolle K., Geurts T., Walstra P., Properties of acid casein gels made by acidification with gluconodelta-lactone. II. Syneresis, permeability and microstructural properties, Int. Dairy J. 7 (1997) 389-397.

[19] Schellhaass S.M., Morris H.A., Rheological and scanning electron microscopic examination of skim milk gels obtained by fermenting with ropy and non-ropy strains of lactic acid bacteria, Food Microstruct. 4 (1985) 279-287.

[20] Tamime A.Y., Kalab M., Davies G., Microstructure of set-style yoghurt manufactured from cow's milk fortified by various methods, Food Microstruct. 3 (1984) 83-92.

[21] Vetier N., Desobry-Banon S., Ould-Eleya M.M., Hardy J., Effect of temperature and acification rate on the fractal dimension of acidified casein aggregates, J. Dairy Sci. 80 (1997) 3131-3166. 